\title{
Maksimilijan Matjaž, novi celjski škof, zavezan ekumenski in dialoški misli
}

\author{
Maksimilijan Matjaž, the New Bishop of Celje, \\ Committed to Ecumenical and Dialogical Thought
}

Papež Frančišek je po skoraj treh letih izpraznjenega škofijskega sedeža mesta grofov za novega celjskega škofa imenoval dr. Maksimilijana Matjaža, duhovnika mariborske nadškofije. Nasledil je škofa Stanislava Lipovška, ki je leta 2018, ko je dopolnil 75 let, papežu Frančišku v skladu s splošno prakso Katoliške cerkve ponudil odstop.

V nadaljevanju ne bomo povzemali dosedanjega življenja, izobraževanja in delovanja novega škofa v Celju, saj so to storile že mnoge revije in mediji, temveč bomo orisali in povzeli njegovo ekumensko dejavnost in misel, ki doslej nista bili poudarjeni. Prizadevanje za dialog usmerja pogled Cerkve $\mathrm{v}$ prihodnost in je $\mathrm{v}$ današnjem prostoru, izpostavljenem globalnemu prepihu, ena od prioritetnih nalog vesoljne Cerkve. Že papež Janez Pavel II. je v svoji znameniti okrožnici Da bi bili eno (Ut unum sint) predstavil dialog kot prednost in obvezno pot, na kateri se odkriva bogastvo drugih. Po tej poti sta svoj pontifikat nadaljevala oba njegova naslednika, Benedikt XVI. in Frančišek.

\section{Teološki dialog v besedi}

»Pri tem postaja vedno bolj jasno, da vseh različnih mednacionalnih in medverskih konfliktov ne bo mogoče reševati brez poglobljenega 
poznavanja temeljnih kulturnih, verskih in narodnih vrednot, ki predstavljajo humus vsake družbe. Najučinkovitejši način preprečevanja bodočih spopadov in vojn je vzgoja za dialog, ki mora potekati tako med posamezniki kot med kulturami. Samo to bo lahko pripeljalo do boljšega poznavanja in spoštovanja drug drugega ter do medsebojnega sodelovanja," zapiše dr. Matjaž v uvodniku v posebno številko revije Edinost in dialog (2016), ki je obravnavala različne vidike dialoga in ekumenske teologije v njihovem soočanju s sodobnimi izzivi. Spori in krize se gotovo ne morejo rešiti zgolj z akademskim teološkim dialogom, saj je "potreben tudi praktičen ekumenizem dejavne ljubezni«, vendar, nadaljuje, »lahko tudi poglobljen premislek o vprašanjih, ki nas povezujejo ali ločujejo, vodi $\mathrm{k}$ večjemu medsebojnemu zaupanju in ustvarjalnemu sodelovanju v dobro vseh.«

Dr. Matjaž je kot glavni in odgovorni urednik zadnja leta urejal revijo Edinost in dialog. Ob ustanovitvi Inštituta za ekumensko teologijo in medreligijski dialog, poimenovanega po Stanku Janežiču, še enem velikanu ekumenske misli na Slovenskem, je Teološka fakulteta Univerze v Ljubljani z Enoto v Mariboru prevzela uredništvo in izdajanje nove serije osrednje slovenske ekumenske revije s tradicijo, ki sega v leto 1927 in je v prenovljeni podobi izšla leta 2013. Zaradi novih vsebinskih in organizacijskih razmer jo je preoblikoval $v$ mednarodno znanstveno revijo $\mathrm{z}$ recenzijo, ki se je uvrstila $\mathrm{v}$ pomembne mednarodne baze znanstvenih publikacij: ATLA Religion Database (American Theological Library Association); ERIH PLUS (European Reference Index for the Humanities); IxTheo (Index Theologicus); RTA (Religious and Theological Abstracts); Scopus.

Revija je pod uredništvom dr. Matjaža ohranila tradicijo ekumenske ideje, ki se $\mathrm{v}$ novih verskih in kulturnih razmerah usmerja tudi v dialog z drugimi verstvi, ter tako v slovenskem prostoru spodbujala najširši teološki in medkulturni dialog. Revija je pod vodstvom dr. Matjaža v relativno kratkem času postala prepoznavna tudi v mednarodnem prostoru, kar na svoj način odraža dejstvo, da zadnji dve leti ne izdaja več ene številke letno, temveč dve. Vsaka številka je bila skrbno načrtovana in posvečena posebni ekumenski oz. medverski temi.

V nadaljevanju bomo navedli samo nekaj primerov. Druga številka v letu 2020 in pričujoča, prva v letu 2021, je v sodelovanju s Centrom judovske 
kulturne dediščine Sinagoga Maribor in s podporo raziskovalnega programa Judovsko-krščanski viri in razsežnosti pravičnosti P6-0262(A) ARRS obeležila 55. obletnico objave koncilske izjave Nostra Aetate, ki je omogočila sistematičen dialog med Katoliško cerkvijo in judovstvom. V drugi številki letnika 2019 in v prvi številki letnika 2020 je revija objavila tematske razprave o dialogu med kristjani in muslimani. Številka letnika 2017 je obeležila spomin petstoletnice reformacije, ki je omogočil nov pogled na dogodke v 16. stoletju, ki so vodili do razkola ...

Na začetku izhajanja nove serije revije je dr. Dolenc v uvodniku povzel vlogo in mesto revije in $s$ tem tudi njenega glavnega in odgovornega urednika: »Menim, da je ekumenski duh premagovanja ločilnih zidov in iskanja 'edinosti v različnosti' v slovenskem prostoru živo navzoč vse od blaženega A. M. Slomška dalje. Saj se vendar vsi trudimo hoditi za Njim, ki 'je naš mir,' za Njim, 'ki je iz obeh napravil eno, s tem da je podrl steno pregrade, to je sovraštvo' (Ef 2,14). Zlasti se je ta duh okrepil v preteklem stoletju, s koncilom pa je postal nepreklicna odločitev in zaveza celotne Cerkve in samoumevna razsežnost našega oznanjevanja. Tega duha so med nami budili navdušenci in garači ob reviji Kraljestvo božje in ekumenskem zborniku Vedinosti, ki sta predhodnika pričujoče revije Edinost in dialog."

\section{Teološki dialog v dejanjih}

Revija je v svojem kratkem obstoju organizirala dva večja in odmevnejša simpozija. Prvega leta $2014 \mathrm{z}$ naslovom Teologija v dialogu. V sedemdesetih in osemdesetih letih prejšnjega stoletja (od 1974 do 1990) so tri teološke fakultete v bivši skupni državi (obe katoliški - v Ljubljani in Zagrebu - ter pravoslavna $v$ Beogradu) priredile devet medfakultetnih ekumenskih simpozijev. Misel o nadaljevanju te dediščine je bila večkrat izražena s strani vseh treh fakultet, določen sklep o oživitvi pa je nastal ob mednarodnem ekumenskem in medverskem simpoziju v okviru prireditev Maribora kot Evropske prestolnice kulture jeseni 2012 v Mariboru. Ob 40. obletnici prvega od medfakultetnih simpozijev, ki je bil v Mariboru (1974), in upoštevajoč nov politični in kulturni okvir, je v Mariboru od 16. do 18. oktobra 2014 potekal mednarodni ekumenski simpozij Teologija v dia$\log u$, ki je napovedal ponovno oživitev ekumenske in dialoške tradicije v Mariboru in Sloveniji. Na simpoziju je sodelovalo več kot 50 domačih 
in tujih strokovnjakov in doktorskih študentov. Med ključnimi organizatorji je bil prav dr. Matjaž, ki izvedbo tudi finančno omogočil, saj je bil simpozij organiziran vzporedno z mednarodno znanstveno delavnico Moč in nemoč besede $v$ družbenem dialogu, katere nosilec je bil dr. Matjaž.

Drugega je revija organizirala aprila 2021 vzporedno s posebnima številkama, ki sta obeležili 55. obletnico objave koncilske izjave Nostra Aetate. Simpozij obravnava teološka, zgodovinska in kulturna vprašanja, oblikovana $\mathrm{v}$ zadnjih desetletjih, in poudari poseben status judovsko-katoliškega dialoga, saj judovske korenine krščanstva na edinstven način določajo njun medsebojni dialog in medsebojno razumevanje. Na simpoziju je sodelovalo 40 domačih in tujih strokovnjakov. Prvopodpisani organizator tega dogajanja je dr. Matjaž.

Kot glavni in odgovorni urednik je dr. Matjaž tudi član Slovenskega ekumenskega sveta, ki je bil z odlokom slovenskih škofov ustanovljen leta 1965 in leta 2017 preoblikovan v Komisijo za ekumenizem in medreligijski dialog pri Slovenski škofovski konferenci. Komisija ima posebno nalogo, da v duhu drugega vatikanskega koncila spremlja, animira in usmerja mnogovrstne pobude, da bi kristjani v večji meri uresničevali Jezusovo zapoved o edinosti in ljubezni, ki je razpoznavno znamenje Jezusovih učencev (Jn 13, 35). V tem duhu je bil pobudnik in soorganizator več ekumenskih in medreligijskih dogodkov in omizij, ki so se zvrstili zadnja leta v času tedna ekumenske edinosti: leta 2015 omizje z naslovom Od konflikta do občestva: dialog med katoliško in luteransko teologijo, 2016 omizje z naslovom Ali se je v Evropi zgodil trk civilizacij, 2017 omizje z naslovom Na sledi evropski prelomnici: Martin Luter 500 let kasneje, istega leta tudi predstavitev revije in knjige Post - pot v življenje avtorja dr. Vladimirja Vukašinovića s Pravoslavne teološke fakultete v Beogradu.

\section{Od besede do skupnosti}

Nenazadnje je nujno omeniti tudi strokovne in znanstvene razprave dr. Matjaža, od katerih je mnoge posvetil prav ekumenizmu in dialogu. Omejili se bomo na »jagodni izbor «. V zborniku Vedinosti 64 (2009), predhodniku revije Edinost in dialog, je objavil razpravo z naslovom Apostol Pavel glasnik in orodje edinosti: razmišljanje ob Tednu krščanske edinosti. Med 
drugim poudari: »Apostol Pavel v svojih pismih vedno znova nagovarja temo edinosti. Hrepenenje po edinosti se kaže kot eden najmočnejših vzgibov, ki ga žene kot človeka, kot Juda in kot Kristusovega služabnika. Zaveda se, da sta needinost in razdor prva in usodna posledica greha. O tem ga uči odrešenjska zgodovina vse od Adama do Kristusa in do Kristusove Cerkve. Apostol razmišlja o edinosti na treh ravneh: kot človek, kot Jud in kot kristjan. Vsaka od teh treh ravni ima svoje izhodišče oziroma svoj kraj - topos, kjer lahko to edinost ali needinost izkuša in jo gradi. Za Pavla kot človeka je temeljno izkustvo edinosti najprej telo, za Pavla kot Juda je temelj edinosti zaveza, ki jo je Bog sklenil s človeštvom po Abrahamovi veri, za Pavla kot novega človeka v Kristusu pa je absolutni temelj edinosti Jezus Kristus.»

V razpravi, naslovljeni Beseda kot dialog, objavljeni v Bogoslovskem vestniku 2013 (1), poudari pomembnost prizadevanja za besedo kot temeljno enoto vsakega dialoga, Boga s človekom in človeka s sočlovekom. K bistvenemu poslanstvu kultur, utemeljenih na Svetem pismu, »sodi, da razvija logos v njenem najširšem pomenu kot misel, smisel, modrost, razum, znanje, lepoto, kulturo, dušo. To besedo v vseh njenih dimenzijah, ki jo človek potrebuje kakor kruh za svoje preživetje, mora braniti, ohranjati, raziskovati, negovati in promovirati, da se bo lahko uporabljala v svoj temeljni namen, to je za človekovo izrekanje, sporazumevanje in sobivanje, skratka: za življenje."

Končno omenimo še »domač« članek, objavljen v Edinosti in dialogu 2019 (1), z naslovom Občestvo kljub različnosti. Pavlovo razumevanje koinonie $v$ Pismu Galačanom (Gal 2,9). Članek obravnava biblični model reševanja konfliktov in iskanja edinosti ob srečevanju različnih kultur: »Vključevanje drugega in dobrodelnost sta tudi značilnosti 'apostolskega občestva', ki so ga slovesno potrdili predstavniki Cerkve ob sklepu apostolskega zbora v Jeruzalemu (Gal 2,9).« Poleg kristološke in ekleziološke dimenzije Pavlovega pisma Galačanom dr. Matjaž izpostavi Pavlov koncept občestva, ki je podlaga za njegovo razumevanje Cerkve, s tem pa dobi močno univerzalno-ekumensko in misijonsko-etično dimenzijo.

V tej notici o imenovanju novega škofa, ki bo gotovo tudi v prihodnje močno zavezan ekumenski in dialoški misli, žal ni mogoče zaobjeti celotnega mozaika, vendar so delčki, ki smo jih osvetlili, dovolj nazorni, da kažejo jasno podobno in usmeritev. Ta se končno kaže v občestvu, z mnogimi 
osebnimi in prijateljskimi stiki z različnimi občestvi različnih držav, npr. z dosedanjim zagrebško-ljubljanskim metropolitom Porfirijem Perićem, ki je bil nedavno izvoljen za 46. srbskega patriarha. Imenovanje dr. Matjaža za škofa v Celju na ravni Cerkve na Slovenskem predstavlja zagotovilo, da bomo kristjani med seboj in v razmerju do drugače verujočih tudi v prihodnosti zavezani dialogu ter medsebojnemu vzajemnemu spoštovanju. 